\title{
Pengaruh Potensi, Persepsi, dan Preferensi terhadap Sikap dalam Wakaf Uang pada Masyarakat Muslim Kota Semarang
}

\author{
Umi Khoiriyah \\ Jurusan Akuntansi, Fakultas Ekonomi, Universitas Wahid Hasyim \\ Email: khoiriyahumi31@gmail.com
}

\begin{abstract}
Abstrak
Wakaf uang adalah salah satu bentuk wakaf yang diberikan oleh waif kepada nadzir dalam bentuk uang. Penelitian ini bertujuan untuk menjawab pertanyaan tentang bagaimana potensi, persepsi, dan preferensi dapat mendorong sikap komunitas Muslim kota Semarang untuk mewakili uang. Metode pengumpulan data dalam penelitian ini dengan membagikan kuesioner kepada komunitas Muslim kota Semarang sebanyak 270 responden di 5 kecamatan. Data yang terkumpul dianalisis menggunakan uji validitas, uji reliabilitas, uji asumsi klasik, uji regresi linier berganda dan uji $t$, uji hipotesis $f$, dan koefisien determinasi. Hasil penelitian ini secara parsial menunjukkan bahwa variabel potensial memiliki pengaruh yang signifikan terhadap sikap masyarakat muslim kota Semarang, yang diketahui bahwa nilai thitung 2,005> ttabel 1,969 dan nilai signifikansi 0,046 <0,05. Sementara variabel persepsi memiliki pengaruh yang signifikan terhadap sikap komunitas Muslim di kota Semarang, diketahui bahwa thitung 2,832> ttabel 1,969 dan nilai signifikansi 0,005 <0,05. Serta variabel preferensi memiliki pengaruh yang signifikan terhadap sikap komunitas Muslim kota Semarang, diketahui bahwa thitung 3,595>t tabel 1,969 dan nilai signifikan 0,000 <0,05. Sedangkan hasil penelitian secara simultan menunjukkan bahwa variabel potensial, persepsi, dan preferensi memiliki pengaruh yang signifikan terhadap sikap masyarakat muslim kota Semarang, yang diketahui bahwa nilai yang dihitung sebesar 11,399> f tabel 2,65 dan nilai signifikan 0,000 <0,05.
\end{abstract}

Kata kunci: Potensi, Persepsi, Preferensi, Uang Wakaf

\section{PENDAHULUAN}

Menurut agama Islam dibebaskan dalam hal bersedekah, yakni boleh dengan zakat, infaq, sadaqah, dan wakaf. Semua itu merupakan perbuatan yang sangat mulia, sehingga dapat membantu masyarakat sekitar yang perekonomiannya masih terbilang rendah. Wakaf diambil dari kata waqafa yang menurut bahasa berarti menahan atau berhenti. Dalam hukum islam, wakaf berarti menyerahkan suatu hak milik yang tahan lama (zatnya) kepada seorang nadzir (penjaga wakaf), baik berupa perorangan maupun badan pengelola dengan ketentuan bahwa hasil atau manfaatnya digunakan untuk hal-hal yang sesuai dengan syariat Islam (Heri Sudarsono, 2004:35). Bentuk wakaf jenisnya bervariasi dalam berbagai bentuk asset, yang jika diqiyaskan (persamaan hukum) dapat dikelompokkan menjadi asset tidak bergerak (tanah), asset bergerak, dan asset dalam bentuk uang (dinar).

Wakaf dalam bentuk benda bergerak yang meliputi uang, logam mulia, surat berharga, dan benda bergerak lain yang sesuai dengan syariah akhir-akhir ini mengalami peningkatan. Diantara wakaf benda bergerak yang saat ini ramai diperbincangkan adalah wakaf uang. Wakaf uang dikatakan dapat menjadi alternatif yang baik dalam rangka memberdayakan ekonomi rakyat yang dapat membantu untuk mengurangi kemiskinan. Untuk itu perlu dilakukan berbagai upaya untuk memberikan pemahaman terhadap wakaf agar tujuan dan fungsi dari perwakafan tersebut dapat tercapai secara optimal dan dirasakan manfaatnya oleh masyarakat (Fatmah Azis, 2008:1). Menurut Djunaidi, (2007:3) wakaf uang merupakan wakaf yang dilakukan seseorang, kelompok orang, dan lembaga atau badan hukum dalam bentuk uang.

Adapun manfaat wakaf uang yaitu. Pertama, wakaf uang jumlahnya bisa bervariasi sehingga seseorang yang memiliki dana terbatas sudah bisa memberikan dana wakafnya tanpa harus menunggu menjadi orang yang berpendapatan tinggi terlebih dahulu. Kedua, melalui wakaf uang, aset-aset wakaf yang berupa tanah-tanah kosong bisa dimanfaatkan dengan pembangunan gedung atau diolah untuk lahanpertanian. Ketiga, dana wakaf uang juga bisa membantu sebagian lembagalembaga pendidikan islam. Keempat, umat islam dapat lebih mandiri dalam mengembangkan dunia 
pendidikan maupun lembaga kemasyarakatan lainnya tanpa menunggu bantuan dari pemerintah (Jaih Mubarok, 2008:125 dalam Ellen Kurnia Sari Sholihah, 2017:5).

Menurut Cholil Nafis (2009:3) potensi wakaf di Indonesia jika 20 juta umat Islam di Indonesia mau mengumpulkan wakaf uang senilai Rp 100.000 setiap bulan, maka dana yang terkumpul berjumlah Rp 24 triliun setiap tahun. Jika 50 juta orang yang berwakaf, maka setiap tahun akan terkumpul dana wakaf sebesar Rp 60 triliun. Jika saja terdapat 1 juta umat muslim yang mewakafkan dananya sebesar Rp 100.000 per bulan, maka akan diperoleh pengumpulan dana wakaf sebesar Rp 100 miliar setiap bulan dan setiap tahun akan terkumpul Rp 1,2 triliun (Cholil Nafis, 2009 dalam Bashlul Hazami, 2016).

Rendahnya penghimpunan wakaf uang, salah satu penyebabnya adalah pemahaman masyarakat tentang wakaf uang sangat terbatas, jika dibandingkan dengan pemahaman mereka tentang zakat, infaq, dan sadaqah. Hal ini terjadi karena masalah perwakafan kurang dijelaskan oleh para pendakwah, guru agama maupun muballig. Sebagai akibat kurangnya pemahaman umat Islam terhadap lembaga wakaf, maka jarang umat Islam melaksanakannya (Uswatun Hasanah, 1997 dalam Ahmad Nizar, 2014). Proses penghimpunan wakaf uang sendiri masih terdapat beberapa kendala, faktor penyebabnya diantaranya adalah potensi, persepsi, dan preferensi masyarakat yang belum mengerti mengenai wakaf uang.

Sikap ini dapat bersifat positif, dan dapat pula bersifat negatif. Dalam sikap positif, kecenderungan tindakan adalah mendekati, menyenangi dan mengharapkan objek tertentu, sedangkan dalam sikap negatif terdapat kecenderungan untuk menjauhi, menghindari dan tidak menyukai objek tertentu. Sikap positif terhadap produk tersebut akan memungkinkan konsumen menggunakan produk tersebut, sebaliknya sikap negatif akan menghalangi konsumen untuk menggunakan produk tersebut (Dani Panca Setiasih, 2011). Istilah sikap dalam bahasa Inggris disebut attitudes, yaitu sikap terhadap objek tertentu yang merupakan cara memandang atau merasa, yang disertai oleh adanya kecendrungan untuk bertindak sesuai dengan pandangan atau perasaan terhadap objek tersebut (Hani Juliana, 2017:9). Sikap menurut Kotler (2008) merupakan evaluasi dalam waktu lama tentang yang disukai atau tidak disukai seseorang, perasaan emosional, dan kecenderungan tindakan terhadap beberapa objek atau ide. Sikap diartikan sebagai kecenderungan terpelajar untuk memberikan tanggapan dengan cara yang menyenangkan atau tidak menyenangkan dengan respon terhadap suatu objek (Robert Kreitner, 2014). Indikator sikap yang digunakan adalah keyakinan dan kepercayaan (Dani Panca Setiasih, 2011).

Potensi berasal dari bahasa latin yaitu potentia yang artinya kemampuan. Menurut Kamus Besar Bahasa Indonesia potensi merupakan kesanggupan, kekuatan, dan kemampuan dari seseorang yang mempunyai kemungkinan untuk dikembangkan (Desy Anwar, 2003). Dalam kamus ilmiah, potensi diartikan sebagai kekuatan, kesanggupan, kemampuan, kekuatan, pengaruh, daya dan kefungsian. Potensi adalah kemampuan yang belum dibukakan, kuasa yang tersimpan, kekuatan yang belum tersentuh, keberhasilan yang belum digunakan, karunia yang tersembunyi atau dengan kata lain potensi adalah kemampuan atau kekuatan atau daya, dimana potensi dapat merupakan bawaan atau bakat dan hasil stimulus atau latihan dalam perkembangan. Pengukuran potensi dalam penelitian ini yaitu : Demografi yaitu umur, jenis kelamin, pendidikan. Ekonomi yaitu pendapatan, status pekerjaan, religiusitas, nominal sumbangan, dan jumlah menyumbang.

Potensi dapat dilihat dari pendapatan masyarakat yang memiliki penghasilan yang memadai, yaitu masyarakat yang memiliki pengahsilan UMR kota Semarang 2017. Menurut Reksoprayitno, 2004:79 mendefinisikan pendapatan dapat diartikan sebagai total penerimaan yang diperoleh pada periode tertentu. Pendapatan masyarakat adalah penerimaan dari gaji atau balas jasa dari hasil usaha yang diperoleh individu atau kelompok rumah tangga dalam satu bulan dan digunakan untuk memenuhi kebutuhan sehari-hari. Indikator potensi yang digunakan yaitu umur, jenis kelamin, pendidikan, pendapatan, status pekerjaan, religiusitas, nominal sumbangan, dan jumlah menyumbang (Ellen Kurnia Sari Sholihah, 2017).

Menurut Bimo Walgito (2004:70) mengungkapkan bahwa persepsi merupakan suatu proses pengorganisasian, penginterpretasian terhadap stimulus yang diterima organisme atau individu sehingga menjadi sesuatu yang berarti, dan merupakan aktivitas yang integrated dalam diri individu. Setiap orang mempunyai kecenderungan dalam melihat benda yang sama dengan cara 
yang berbeda-beda. Perbedaan tersebut bisa dipengaruhi oleh banyak faktor, diantaranya adalah pengetahuan, pengalaman dan sudut pandangnya.

Persepsi didefinisikan oleh Kotler (2008) sebagai proses seseorang individu dalam memilih, mengatur dan menerjemahkan masukan informasi untuk menciptakan gambaran dunia yang berarti. Poin utamanya adalah bahwa persepsi tidak hanya tergantung pada rangsangan fisik, tetapi juga pada hubungan rangsangan terhadap bidang yang mengelilinginya dan kondisi dalam setiap diri individu. Schiffman dan Kanuk (2008) mendefinisikan persepsi sebagai proses dimana individu memilih, mengorganisasi dan mengintepretasikan stimuli ke dalam gambaran yang mempunyai arti dan masuk akal sehingga dapat dimengerti. Indikator dari persepsi yang digunakan yaitu informasi dan pemahaman produk (Dani Panca Setiasih, 2011).

Preferensi adalah hak untuk didahulukan dan diutamakan dari pada yang lain, atau prioritas, pilihan, kecenderungan, dan kesukaan (Lisna Nety Herawati, 2011). Preferensi adalah sesuatu yang lebih diminati, suatu pilihan utama atau penilaian atas suatu hal dan memberi keuntungan yang lebih baik (Putu Sihendra, 2007). Pada dasarnya, preferensi dalam ekonomi dan ekonomi Islam sangat jauh berbeda. Di dalam prinsip ekonomi kapitalis, preferensi ini hanya bersifat keuntungan. Berbeda di dalam Islam, yang dinamakan preferensi ini haruslah bertujuan untuk memperoleh kesejahteraan ekonomi, distribusi yang seimbang, mempunyai komitmen yang tinggi tentang persaudaraan, serta kemaslahatan. Karena, Islam tidak hanya menilai sesuatu atau mengukur keinginannya dengan rasionalitas, kebebasan ekonomi, dan utilitas (memaksimalisasi nilai guna). (Kurniawati Meylianingrum, 2017). Indikator Preferensi yang digunakan yaitu seleksi, kriteria, dan memilih (Dani Panca Setiasih, 2011).

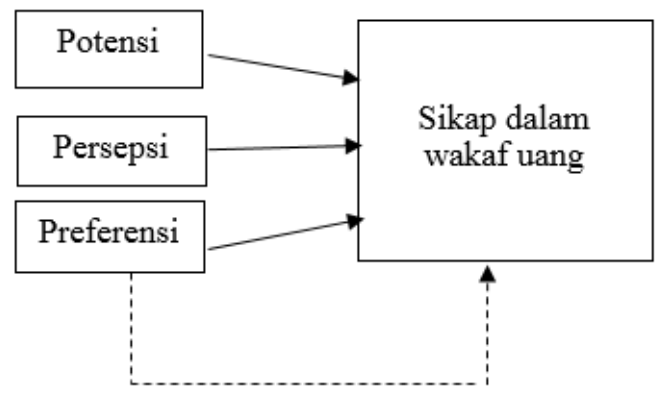

\section{Gambar 1. Kerangka Pemikiran Teoritis}

H1 : potensi berpengaruh positif terhadap sikap dalam wakaf uang pada masyarakat muslim kota Semarang.

$\mathrm{H} 2$ : persepsi berpengaruh positif terhadap sikap dalam wakaf uang pada masyarakat muslim kota Semarang.

H3 : preferensi berpengaruh positif terhadap sikap dalam wakaf uang pada masyarakat muslim kota Semarang.

H4 : potensi, persepsi, dan preferensi secara bersama berpengaruh positif terhadap sikap dalam wakaf uang pada masyarakat muslim kota Semarang.

\section{METODE PENELITIAN \\ Populasi Dan Sampel}

Populasi adalah keseluruhan subjek penelitian. Populasi dalam penelitian ini adalah masyarakat muslim kota Semarang yang berjumlah 1.335.587 orang. Sampel adalah bagian dari jumlah dan karakteristik yang dimiliki oleh populasi tersebut. Teknik pengambilan sampel pada penelitian ini menggunakan teknik cluster sampling (area sampling). Teknik cluster sampling ini dilakukan dengan dua tahap yaitu:

1. Tahap penentuan daerah adalah tahap penentuan sampel daerah dengan cara melihat data masyarakat muslim Kota Semarang yang terdiri dari 16 kecamatan dan dipilih menjadi 5 kecamatan dengan jumlah masyarakat muslim yang paling banyak yaitu Kecamatan Pedurungan, Tembalang, Semarang Barat, Ngaliyan, Dan Banyumanik. 
2. Tahap penentuan individu menurut Suharsimi Arikunto $(2010,112)$ yaitu, jika subjeknya kurang dari 100 orang sebaiknya diambil semuanya, jika subjeknya besar atau lebih dari 100 orang dapat diambil $10-15 \%$ atau $20-25 \%$ atau lebih. Berdasarkan jumlah populasi masyarakat muslim kota Semarang 1.335.587 orang, sampel yang diambil 20\% dari jumlah populasi, sehingga jumlah sampelnya adalah 270 responden.

\section{Jenis Dan Sumber Data}

Penelitian ini menggunakan penelitian kuantitatif, yaitu penelitian yang menekankan pada pembuktian hipotesis yang disusun dari rumusan masalah yang dikemukakan, kemudian menggunakan data yang terukur dan menghasilkan kesimpulan yang dapat digeneralisasikan. Sumber data yang digunakan adalah data primer. Data primer yaitu bersumber dari data kuesioner. Kuesioner adalah cara pengumpulan data dengan memberikan atau menyebarkan daftar pertayaan kepada responden dengan harapan responden merespon daftar pertanyaan tersebut. Data primer diperoleh secara langsung dari responden yaitu masyarakat muslim kota Semarang dengan mengisi lembar kuesioner.

\section{Metode Analisis}

Uji validitas adalah suatu ukuran yang menunjukkan tingkatan-tingkatan kevalitan dan kevasihan suatu instrument. Sedangkan uji reliabilitas merupakan alat yang digunakan untuk mengetahui sseberapa jauh hasil pengukuran tetap konsisten apabila dilakukan pengukuran dua kali atau lebih terhadap gejala yang sama dan alat ukur yang sama.

Uji Asumsi Klasik antara lain Uji normalitas dilakukan untuk menguji apakah dalam sebuah model regresi variabel dependen, variabel independen atau keduanya mempunyai distribusi normal atau tidak, Uji heteroskedastisitas bertujuan untuk menguji apakah dalam model regresi terjadi ketidaksamaan variance dari residual satu pengamatan ke pengamatan lain, Uji multikolinearitas, digunakan untuk menguji apakah dalam model regresi ditemukan adanya korelasi antara variabel independen.

Analisis Regresi Linier Berganda. Analisis data yang diteliti dalam penelitian ini menggunakan analisis regresi linier berganda dapat dilihat pada rumus berikut:

$$
Y=a+b_{1} X_{1}+b_{2} X_{2}+b_{3} X_{3}+\varepsilon
$$

Uji parsial (t statistik) yaitu Uji t statistik suatu uji hipotesis terhadap koefisisen regresi parsial yang digunakan untuk melihat pengaruh masing-masing variabel independen secara individual terhadap variabel dependennya.

Uji simultan (f statistik) digunanakan untuk mengetahui pengaruh variabel independen secara bersamal (potensi, persepsi, preferensi) terhadap variabel dependen (sikap). Koefisien determinasi $\left(\mathrm{R}^{2}\right)$ Koefisien determinasi menunjukkan suatu proporsi dari varian yang diterangkan terhadap varian total.

\section{HASIL DAN PEMBAHASAN}

Responden penelitian 258 responden dengan berjenis kelamin perempuan 154 orang, dengan mayoritas berusia 20-30 tahun, dengan tingkat pendidikan SMA, bekerja sebagai wiraswasta, dengan pendapatan per bulan Rp 2.300.000 - Rp 5.000.000, dengan rata-rata melakukan sholat 5 waktu dan sholat sunah serta berpuasa ramadhan dan berpuasa sunah, memberikan sumbangan tidak rutin setiap bulan dengan nominal $\mathrm{Rp} 0$ - Rp 50.000 .

Berdasarkan hasil olah data diketahui bahwa variabel potensi berpengaruh signifikan terhadap sikap masyarakat muslim kota Semarang. Hasil uji variabel potensi secara parsial memiliki t hitung 2,005 > t tabel 1,969 dan tingkat signifikan 0,046 $<0,05$ yang berarti membuktikan bahwa variabel potensi berpengaruh signifikan terhadap sikap masyarakat muslim kota Semarang yang artinya semakin tinggi potensi masyarakat maka kesadaran untuk berwakaf uang semakin meningkat. Hal ini dikarenakan responden menyatakan bahwa wakaf uang lebih mudah untuk dilakukan tanpa harus menunggu menjadi tuan tanah terlebih dahulu. Sehingga masyarakat muslim kota Semarang yang memiliki pendapatan yang memadai dapat menjadikan masyarakat mempunyai kecenderungan untuk berwakaf uang. Menurut Adioetomo dan 
Moertiningsih, 2005 faktor ekonomi dan demografi dapat memacu investasi dan pertumbuhan ekonomi. Selain itu, secara ekonomi wakaf uang ini sangat besar potensinya untuk dikembangkan, karena dengan model wakaf uang ini daya jangkau dan mobilitasnya akan jauh lebih merata di tengah-tengah masyarakat dibandingkan dengan model wakaf tradisional (wakaf dalam bentuk tanah dan bangunan). Sebab wakaf dalam bentuk tanah dan bangunan hanya dapat dilakukan oleh keluarga atau individu yang terbilang mampu (kaya) saja (Hasan Mansyur Nasution, 2010:109).

Berdasarkan hasil olah data diketahui bahwa variabel persepsi berpengaruh signifikan terhadap sikap masyarakat muslim kota Semarang. Hasil uji hipotesis variabel persepsi secara parsial memiliki thitung 2,832 > t tabel 1,969 dan tingkat signifikan 0,005 $<0,05$, yang berarti membuktikan bahwa variabel persepsi berpengaruh signifikan terhadap sikap masyarakat muslim kota Semarang, yang artinya persepsi masyarakat muslim kota Semarang yang terbentuk dari pernyataan persepsional yang distimuli oleh indra memutuskan untuk menyikapi wakaf uang. Masyarakat muslim kota Semarang melalui informasi tentang wakaf dan pemahaman tentang wakaf uang dapat menjadikan masyarakat mempunyai kecenderungan untuk berwakaf uang, serta masyarakat dapat mengartikan bahwa wakaf uang sebagai salah satu wakaf yang bermanfaat bagi kesejahteraan umat. Oleh karena itu, untuk meningkatkan wakaf uang maka harus meningkatkan persepsi dari masyarakat muslim Kota Semarang. Persepsi yang positif harus ditingkatkan dengan cara suka membaca buku-buku agama Islam, suka mengikuti pengajian, dan mendengarkan ceramah tentang pengetahuan agama Islam. Dengan semakin luasnya pengetahuan agama seorang muslim maka persepsi masyarakat akan wakaf uang semakin besar karena wakaf uang memiliki kemampuan yang fleksibel dibandingkan wakaf yang lain.

Berdasarkan hasil olah data di atas diketahui bahwa variabel preferensi berpengaruh signifikan terhadap sikap masyarakat muslim kota Semarang. Hasil uji hipotesis variabel preferensi secara parsial memiliki t hitung 3,595 > t tabel 1,969 dan tingkat signifikan 0,05 $<0,000$ yang berarti membuktikan bahwa variabel preferensi berpengaruh signifikan terhadap sikap masyarakat muslim kota Semarang, yang artinya masyarakat muslim kota Semarang menyukai dan mengetahui manfaat wakaf uang yang cukup besar bagi masyarakat, banyak yang mempercayai bahwa wakaf uang dikelola dengan benar dan tidak sulit untuk wakif yang berwakaf uang. Sehingga dari kesukaan tersebut masyarakat tentunya mempunyai kecenderungan untuk berwakaf uang semakin banyak serta banyak yang berpendapat bahwa wakaf uang dapat meningkatkan kesejahteraan umat. Oleh karena itu, untuk meningkatkan penghimpunan wakaf uang maka harus meningkatkan preferensi dari masyarakat muslim Kota Semarang dengan cara lembaga maupun perorangan wakaf uang harus menerapkan sistem keterbukaan kepada wakif ataupun masyarakat bahwa wakaf uang dikelola dengan benar.

Berdasarkan hasil olah data di atas diketahui bahwa variabel potensi (X1), persepsi (X2), dan preferensi (X3) secara simultan berpengaruh signifikan terhadap sikap masyarakat muslim kota Semarang. Hasil uji hipotesis variabel potensi (X1), persepsi (X2), dan preferensi (X3) secara simultan memiliki $\mathrm{f}$ hitung 11,398 > f tabel 2,65 dan tingkat signifikan $0,05<0,000$ yang berarti membuktikan bahwa variabel potensi (X1), persepsi (X2), dan preferensi (X3) berpengaruh signifikan terhadap sikap masyarakat muslim kota Semarang. Sehingga masyarakat muslim kota Semarang yang memiliki pendapatan yang memadai, memiliki pengetahuan agama Islam yang luas, memahami tentang wakaf uang, mengetahui manfaat wakaf uang, mempercayai lembaga ataupun nadzir wakaf uang mengelola dengan benar dan tidak sulit ketika masyarakat akan berwakaf uang serat menerapkan sistem keterbukaan kepada wakif, tentunya masyarakat tersebut akan mempunyai kesanggupan untuk mengeluarkan hartanya dengan berwakaf uang.

\section{KESIMPULAN}

1. Hasil pembahasan variabel potensi masyarakat berpengaruh signifikan terhadap sikap masyarakat muslim kota Semarang untuk berwakaf uang, hal ini berarti semakin tinggi potensi masyarakat muslim kota Semarang maka kesadaran untuk berwakaf uang semakin meningkat.

2. Hasil pembahasan variabel persepsi memiliki pengaruh signifikan terhadap sikap masyarakat muslim kota Semarang untuk berwakaf uang, hal ini berarti pemahaman masyarakat dapat mendorong sikap untuk berwakaf uang. 
3. Hasil pembahasan variabel preferensi masyarakat terhadap sikap untuk wakaf uang memiliki pengaruh signifikan terhadap sikap masyarakat muslim kota Semarang, hal ini berarti kesukaan masyarakat dapat mendorong sikap masyarakat untuk berwakaf uang.

4. Hasil pembahasan variabel potensi, persepsi, dan preferensi secara bersama memiliki pengaruh signifikan terhadap sikap masyarakat muslim kota Semarang, hal ini berarti masyarakat muslim kota Semarang yang memiliki pendapatan yang memadai, memahami tentang wakaf uang, mengetahui manfaat wakaf uang, mempercayai wakaf uang dikelola dengan benar serta tidak sulit melakukannya, maka mempunyai kesanggupan untuk berwakaf uang.

\section{SARAN}

1. Perlu lebih ditingkatkan upaya sosialisasi, baik melalui media interpersonal (kyai/ulama), media elektronik maupun media cetak.

2. Pemerintah atau Badan Wakaf Indonesia juga harus mengoptimalkan informasi seputar wakaf uang, seperti jumlah wakaf uang, pengelolaan dan juga pendistribusian. Sehingga diharapkan dapat meningkatkan kepercayaan masyarakat atas wakaf uang tersebut.

3. Ada banyak variabel yang mempengaruhi sikap masyarakat muslim kota Semarang untuk berwakaf uang selain potensi, persepsi, dan preferensi. Penelitian selanjutnya diharapkan mampu menyertakan pengukuran religiusitas, jumlah menyumbang dalam sebulan dan nominal yang disumbangan dapat dijadikan variabel penelitian selanjutnya agar hasil yang diperoleh lebih luas dan pengetahuan tentang wakaf uang semakin meningkat.

\section{DAFTAR PUSTAKA}

Adioetomo dan Sri Moertiningsih. 2005. Bonus Demografi : Hubungan antara Pertumbuhan Penduduk dengan Pertumbuhan Ekonomi. Jakarta:BKKBN.

Anwar, Desy. 2003. Kamus Besar Bahasa Indonesia. Surabaya: Amelia.

Arikunto, Suharsimi. 2010. Prosedur Penelitian Suatu Pendekatan Praktik. Jakarta: PT Rineka Cipta.

Aziz, Fatmah. 2008. Wakaf Tunai Solusi Alternatif Dalam Rangka Memberdayakan Ekonomi Rakyat. Management and Accounting Journal, Vol III, No. 6.

Djunaidi, Achmad. 2007. Panduan Pemberdayaan Tanah Wakaf Produktif Strategis di Indonesia. Jakarta: Direktorat Pengembangan Zakat dan Wakaf Departemen Agama Republik Indonesia.

Hazami, Bashlul. 2016. Peran dan aplikasi wakaf dalam mewujudkan kesejahteraan umat di Indonesia. Volume XVI, Nomor 1

Herawati, Lisna Nety. 2011. "Preferensi dan Keputusan Masyarakat KecamatanKarawaci dalam Menyalurkan Zakat". Skripsi. Jakarta: UIN Syarif Hidayatullah.

Juliana, Hani. 2017. Hubungan Pengetahuan Dan Sikap Dengan Perilaku Nadhir Di Kecamatan Stabat Kabupaten Langkat Dalam Pemberdayaan Wakaf Produktif. Jurnal At Tawassuth, Vol 2 No 1.

Kotler, Philip dan Keller Kevin Lane. 2008. Manajemen Pemasaran. Jakarta: Erlangga.

Kreitner, Robert dan Angelo Kinichi. 2014. Perilaku Organisasi. Jakarta: Salemba Empat.

Meylianingrum, Kurniawati. 2017. Preferensi Wakif Dalam Memilih Wakaf Uang Di Badan Wakaf Indonesia Wilayah Kota Yogyakarta.Tesis fakultas syariah dan hukum Universitas Negeri Sunan Kalijaga Yogyakarta.

Nasution, Hasan Mansyur. 2010. Wakaf dan Pemberdayaan Umat. Jakarta: Sinar Grafika.

Nizar, Ahmad. 2014. Faktor-faktor yang Mempengaruhi Persepsi Wakif Tentang Wakaf Uang. Jurnal Bisnis dan Manajemen.Vol 4 No 1.

Reksoprayitno. 2004. Sistem ekonomi dan demokrasi ekonomi. Jakarta: Bina Grafika.

Schiffman, Leon dan Kanuk, Leslie Lazar. 2008. Perilaku Konsumen. Jakarta: PT. Indeks.

Setiasih, Dani Panca. 2011. Analisis Persepsi, Preferensi, Sikap Dan Perilsku Dosen Terhadap Perbankan Syariah (Study Kasus Pada Dosen Fakultas Syariah Iain Walisongo Semarang). Skripsi IAIN Walisongo Semarang. 
Sholihah, Ellen Kurnia Sari. 2017. "Pengaruh Potensi, Persepsi, Preferensi, Dan Perilaku Masyarakat Muslim Surabaya Terhadap Wakaf Uang Dengan Sikap Sebagai Variabel Intervening”. Skripsi. Surabaya: Universitas Negeri Sunan Ampel.

Sihendra, Putu dan I G Astawa Dipura. 2007. Analisa Tingkat Preferensi Pegawai Negeri Sipil Pemerintah Kabupaten Bandung. Jurnal Teknik Sipil. Vol 11

Sudarsono, Heri. 2007. Konsep Ekonomi Islam sebagai Pengantar. Yogyakarta.

Walgito, Bimo. 2004. Pengantar Psikologi Umum. Penerbit Andi, Jakarta 